\title{
Assessment of innovation performance of Slovak regions
}

\author{
Eva Ivanová \\ Faculty of Social and Economic Relations \\ Alexander Dubček University of Trenčin \\ Trenčin, Slovakia \\ eva.ivanova@tnuni.sk \\ Jana Masárová \\ Faculty of Social and Economic Relations \\ Alexander Dubček University of Trenčin \\ Trenčin, Slovakia \\ jana.masarova@tnuni.sk
}

Abstract. The paper attempts to evaluate the innovative performance of Slovak regions over the years 2010-2014 by using the selected indicators of innovative performance. The innovation performance of the Slovak regions we evaluated in terms of the following indicators: creation or substantial improvement of new materials, products, equipment; creation of new processes, technological procedures, systems and services or substantial improvement; publications and citations; patents and utility models. The variable standardized method was employed to evaluate the innovation performance of the Slovak regions.

The innovation performance of the Slovak regions was changing continually. In 2010, 2011 and 2013 the highest innovation performance was in Trnava region, in 2012 in Bratislava region, in 2014 in Trencin region. A significantly below the average of innovation performance was found in Prešov region.

Keywords: Innovations, Innovation activity, Research and Development, Innovation Performance.

JEL classification: $\mathrm{O} 10, \mathrm{O} 30, \mathrm{O} 32$

\section{INTRODUCTION}

Innovations are considered to be the driving force of economic and social development of enterprises, regions, national economies, as well as geopolitical integration units. They affect economic growth, employment growth and competitiveness at the regional, national and international levels. Not only businesses are engaged in competition, but also geographic entities, countries, integration groups etc. 
Enterprise competitiveness can be expressed via financial and economic indicators, or export performance, whenever applicable. Innovations are the prerequisite for economic unit competitiveness at all evaluation levels. Research and development is ranked among the key sources of technical innovations that initiate product innovations. It follows from the Frascati Manual (OECD, 2005) that an innovation taking the form of new or significantly improved products (technologies or services) effectively placed at the market are the result of a series of scientific, technical, organizational, financial, commercial and other activities. These activities include research and development. Thus, innovations are the result of effective application of science, research and development in practice.

Corporate sector units are the carriers of innovations. Despite the fact that these entities may show competitiveness as a property associated with their result comparison and development forecasts, competition among enterprises and regions or nations cannot be considered as equal (Ručinská, 2008). In economic theory, there are various opinions on expression of the competitiveness of regions and territories as well as many approaches to the very nature of the existence and competitiveness of territories, regions and nations. When defining the factors that determine the competitiveness of a region, several approaches can be employed. Porter (1990) maintains that there are three types of competitive advantage of nations according to which economies are categorized into: cost-oriented or factor of production-oriented economies, investment-oriented economies, and innovation-oriented economies. For obvious reasons innovation-oriented enterprises are the most successful ones in competition (Apple, Google, Tesla Motors, IBM, and others).

The innovation performance of Slovakia is assessed by the Innovation Union Scoreboard (IUS). The European Innovation Scoreboards provide a comparative assessment of research and innovation performance in Europe. The scoreboards help countries and regions identify the areas they need to address. Regional Innovation Scoreboard (RIS) provides a comparative assessment of innovation performance across 190 regions of the European Union, Norway and Switzerland. RIS is used to comparatively assess Slovak regional performance at NUTS 2 level. According to the IUS assessment, Slovakia lags behind the EU average and in terms of V4 countries it lags behind Hungary and Czech Republic.

The paper attempts to assess the innovation performance at regional NUTS 3 level, which differs from the RIS assessment. The innovation performance of Slovak regions at NUTS 3 level affects the overall innovation level of Slovak Republic and is reflected in the RIS assessment of regions.

\section{THEORETICAL BACKGROUND AND LITERATURE OVERVIEW}

Innovation is a result of a creative process, of a new idea, brain wave, and new knowledge - of invention. The invention is only the first step in a long process. During this process a good idea is transformed in the form of a wide range of a highly useful and effective product or service. New knowledge does not always reach the phase of implementation, it does not become innovation. In the beginning of this process is creative thinking - creativity.

Creativity entails a level of originality and novelty that is essential for innovation. Creativity means the creation of new ideas, whereas innovation means to bring these ideas in a concrete form to the market.

In addition to the terms of creativity and innovations, there is the term of invention. The term invention (from Latin, which means ingeniousness, invention) refers to a scale of knew knowledge as a result of social important activity, scientific exploration, research and development, which cause changes in the knowledge structure and level of knowledge. For the demand of an invention process only the inventions are used, which are supposed to bring a particular developmental change of the product or service, which 
evokes effective changes. Inventions as a result of creative human activity are decisive factors for innovation generation and general economic development.

The term innovation comes from Latin and it means renewal, renovation. Joseph Schumpeter is regarded as the founder of innovation theory. In 1911, he coined the term innovation for "new combinations of developmental changes".

The role of innovations is to create and market new products and services that meet the growing demands of customers on product features, such as variability, performance, efficiency, quality, reliability, durability, operation, design as well as environmental characteristics. Regarding products, customers prefer products featuring novelty, individuality, reasonable price, availability, and convenience of use in accordance with the technical, economic and social progress.

Schumpeter (1934) considered innovations to be only the first entry of a new product, raw materials, technology, etc. on the market, i.e. the first materialization of certain ideas for the market. All other manufacturers were called imitators.

Schumpeter's attention to innovation and entrepreneurship proved ahead of its time; these concerns now lie centre stage in policy discussions about economic development. Entrepreneurs are the agents of change in an economy and the source of increased productivity - those actors who recognize opportunity and garner resources to create value. Innovation and entrepreneurship are two sides of the same coin: Entrepreneurs identify opportunity and innovate, while innovation is the commercial realization of value from a new idea or invention from an entrepreneur. Innovation may result in new products introduced to the market, new production processes or new organizational forms.

In the world literature, the issue of innovation and innovation management, national and regional innovation system is dealt with by a lot of authors who developed the original Schumpeter's theory. Currently, this work focuses mainly on the innovation management in enterprises, creation and use of national and regional innovation systems as a part of innovation policy.

According to most current authors the term innovation is a key term for an enterpriser or manager, they regard as innovation every change, every product, service, process improvement. According to Freeman "innovation includes technical, design-related, managerial and commercial activities which relate to introduction of a new (or improved) product on the market or to the first use commercial use of some new (or improved) process or equipment." (Freemen, 1987)

Lundvall (1992) states that innovations refer to the introduction of new products, services, or resources used to manufacture them to the market, launching new products and processes into the market, including the process of originating a creative idea leading up to its commercial use.

Innovations can be defined as processes by which enterprises put into practice product designs and manufacturing processes that are new to them, irrespective of whether they are simultaneously new in the world. Thus, it is referred to launching products into the market and disseminating technology (Edquist, 1997).

From Drucker's perspective, systematic innovation consisted of the purposeful and organized search for changes, and in the systematic analysis of the opportunities such changes might offer for economic or social innovation. Furthermore, Drucker says: "Innovation is the specific function of entrepreneurship, whether in an existing business, a public service institution, or a new venture started by a lone individual in the family kitchen. It is the means by which the entrepreneur either creates new wealth-producing resources or endows existing resources with enhanced potential for creating wealth."(Drucker, 1993)

Rothwell and Gardiner (1988) connect the importance of incremental innovations to the high rates of technological change. According to them, during periods of high rates of technological change, there exist relatively few radical innovations in each industry. 
Additionally, innovation is defined in the Oslo Manual, Frascati Manual (OECD) and the Act No. 172/2005 Coll. on the organization of state support for research and development and on amendments to the Act. 575/2001 Coll. on the organization of government activities and the organization of central state administration, as amended in Slovakia. Generally, innovation is defined as follows:

Innovation is the process of making changes to something established by introducing something new that adds value to customers.

Michael Porter (1990) in his very influential work, The Competitive Advantage of Nations, identified innovations as the competitive advantage of geographic or entrepreneurial units.

There is growing recognition that innovation encompasses a wide range of activities in addition to $\mathrm{R} \& \mathrm{D}$, such as organisational changes, training, testing, marketing and design. The latest (third) edition of the Oslo Manual defines innovation as the implementation of a new or significantly improved product (good or service) or process, a new marketing method, or a new organisational method in business practices, workplace organisation or external relations. By definition, all innovation must contain a degree of novelty. The Oslo Manual distinguishes three types of novelty: an innovation can be new to the firm, new to the market or new to the world. The first concept covers the diffusion of an existing innovation to a firm - the innovation may have already been implemented by other firms. Innovations are new to the market when the firm is the first to introduce the innovation on its market. An innovation is new to the world when the firm is the first to introduce the innovation for all markets and industries. Innovation rarely occurs in isolation. It is a highly interactive process of collaboration, one that is increasingly international, across a growing and diverse network of stakeholders, institutions and enterprises.

The document Green Paper on Innovation published by European Commission in 2004 is often used to explain the term of innovation. In this document the term innovation is understood as a synonym for successful production, assimilation and novelty use in the economic and social sphere. Innovations offer new solutions of problems and so they make it possible to satisfy the needs of an individual and a society.

Kačírková (2009) considers a region to be the most suitable unit for innovations and learning for the proximity between economic players, common social and institutional space shared by them, fast circulation of knowledge that all support the creation of innovation, cooperation on innovation activities and integration of resources. Concerning regional innovation systems, one needs to understand how national innovation systems work as they are important for the development of regional innovation environment, which is anchored and strongly influenced by national innovation systems.

Ručínska (2008) writes that the innovation performance of an economy or economic unit can be assessed by innovation systems, consisting of regional players and relations among them. Regional innovation system is made up of enterprises, universities and other research institutions, intermediaries, government institutions, public organizations and the third sector. There is mutual exchange of information, goods, people, knowledge and finance among these entities in the region.

There are several authors who stress the importance and relevance of the innovation environment at national and regional levels, such as Harmakorpi (2004, p. 66), Urbancová (2013), Havierniková and Strunz (2014), Sedláček (2014), Rajnoha and Lorincová (2015), Okręglicka (2016), Zastempowski and Przybylska (2016) etc.

The issue of innovation performance of regions is dealt with in the works by Edquist (1997), Kuhlman (2001), Tödtling and Trippl (2005), Teece, Pisano\&Shuen (1997), Urbančíková and Burger (2010), Skokan (2004). 


\section{PURPOSE AND METHODOLOGY}

The variable standardized method was employed to evaluate the innovation performance of the Slovak regions. The method ranks among the multi-criteria evaluation methods, i.e. it is the method considering several factors or criteria, which makes it more effective in capturing the reality.

Multi-criteria evaluation methods are used to examine multivariate statistical series. By using these methods, several indicators can be expressed by one synthetic (aggregate) indicator as a specific number. Subsequently, the resulting indicators, i.e. numbers are arranged from the best to the worst. These methods can be used to evaluate and compare the level of several states or regions on the basis of various indicators.

The advantage of the standard variable method is that it takes into account the relative variability of indicators. The essence of the standard variable method is the transfer of various indicator values to a comparable shape - the so called standardized variable.

Calculation procedure:

1. We calculate arithmetic means $(\bar{x})$ and standard deviations $\left(s_{x}\right)$ for the evaluated variables:

Arithmetic mean:

$$
\bar{x}=\frac{\sum_{i=1}^{n} x_{i}}{n}
$$

Standard deviation equals the square root of the variance:

$$
s_{x}=\sqrt{\frac{1}{n} \sum_{i=1}^{n}\left(x_{i}-\bar{x}\right)^{2}}
$$

2. We transform the original values of indicators $\left(x_{i}\right)$ to standardized variable $\left(x_{i, 1 s}\right)$. The standardized variable is the value of a variable minus its mean, divided by its standard deviation:

$$
x_{i, 1 s}=\frac{x_{i}-\bar{x}}{s_{x}}
$$

Regions with higher indicator values than the mean have positive standardized variable. On the other hand, regions with lower indicator values than the mean have negative standardized variable.

3. Then we calculate the integral indicator $\mathrm{d}_{\mathrm{i}}$, as the sum of standardized variables of the indicators established for each region as follows:

$$
d_{i}=\sum_{i=1}^{n} x_{i, 1 s}
$$

4. Finally, we establish the rankings of regions according to the size of the integral indicator. The best results of observe variable reaches the region in which the integral indicator $d_{i}$ reaches the maximum value.

Explanatory notes:

$x_{i}=$ Each data point $i$

$n \quad=$ File range (number of regions)

$\bar{x}=$ The average of all the sample data points

$s_{x}=$ The standard deviation of all sample data points

$x_{i, 1 s}$ - The data point $i$ standardized to $1 s$, also known as Z-Score

Many researchers have noted the importance of standardizing variables for multivariate analysis. Otherwise, variables measured at different scales do not contribute equally to the analysis. For example, 
in boundary detection, a variable that ranges between 0 and 100 will outweigh a variable that ranges between 0 and 1 . Using these variables without standardization in effect gives the variable with the larger range a weight of 100 in the analysis. Transforming the data to comparable scales can prevent this problem. Typical data standardization procedures equalize the range and/or data variability.

\section{RESULTS AND DISCUSSIONS}

The innovation performance of the Slovak regions is evaluated in terms of the following indicators:

- creation or substantial improvement of new materials, products, equipment (innovation of those being in use),

- creation of new processes, technological procedures, systems and services (including software) or substantial improvement (upgrade of existing ones),

- publications and citations,

- patents and utility models.

These indicators were selected due to their relatively high values compared to the spin-off or start-up indicators listed in the source database of the Statistical Office that provide relevant results in the assessment process.

\section{THE ASSESSMENT OF INNOVATION PERFORMANCE OF THE SLOVAK REGIONS IN 2010}

The starting year of our research is 2010. In order to take account the different number of scientists and researchers, the above indicators of innovation performance were calculated per one researcher working in the given region. The data for 2010 are shown in Table 1.

Table 1

Selected indicators of innovation performance of the Slovak regions per one researcher in 2010

\begin{tabular}{|c|c|c|c|c|}
\hline & $\begin{array}{c}1-\text { new materials, prod- } \\
\text { ucts and equipment }\end{array}$ & $\begin{array}{c}2 \text { - new processes, } \\
\text { technological } \\
\text { procedures }\end{array}$ & $\begin{array}{c}3 \text { - publications and } \\
\text { citations }\end{array}$ & $\begin{array}{c}4 \text { - patents and utility } \\
\text { models }\end{array}$ \\
\hline BA & 0,015093 & 0,013843 & 2,854486 & 0,002585 \\
\hline TT & 0,091879 & 0,009844 & 1,913043 & 0,022149 \\
\hline TN & 0,021407 & 0,028542 & 0,306830 & 0,037717 \\
\hline NR & 0,012195 & 0,017683 & 3,685976 & 0,000610 \\
\hline ZA & 0,023989 & 0,026211 & 1,373612 & 0,004887 \\
\hline BB & 0,004813 & 0,028881 & 1,980144 & 0,004813 \\
\hline PO & 0,005353 & 0,002141 & 1,169165 & 0,007495 \\
\hline KE & 0,005341 & 0,013947 & 2,392285 & 0,008309 \\
\hline
\end{tabular}

BA - Bratislava region, TT - Trnava region, TN - Trenčín region, NR - Nitra region, ZA - Žilina region, BB - Banská Bystrica region, $\mathrm{PO}$ - Prešov region, $\mathrm{KE}-$ Košice region

Source: own calculations on the basis of Ministry of Education, Science, Research and Sport of the Slovak Republic.

The largest share of new materials, products and equipment (indicator 1) per one researcher is found in Trnava region, far followed by Žilina and Trenčín regions. Regarding indicator 2 (new processes, technological 
procedures), the best results are seen in Banská Bystrica, Trenčín and Žilina regions, the worst results in Prešov region. Concerning publications and citations (indicator 3), Nitra region has the largest productivity, followed by Bratislava and Košice regions. Most patents and utility models per researcher are found in Trenčín region, while Nitra and Bratislava regions are lagging behind. A comparison of the productivity of researchers based on selected indicators of innovation performance in the Slovak regions in 2010 is illustrated in Figure 1.

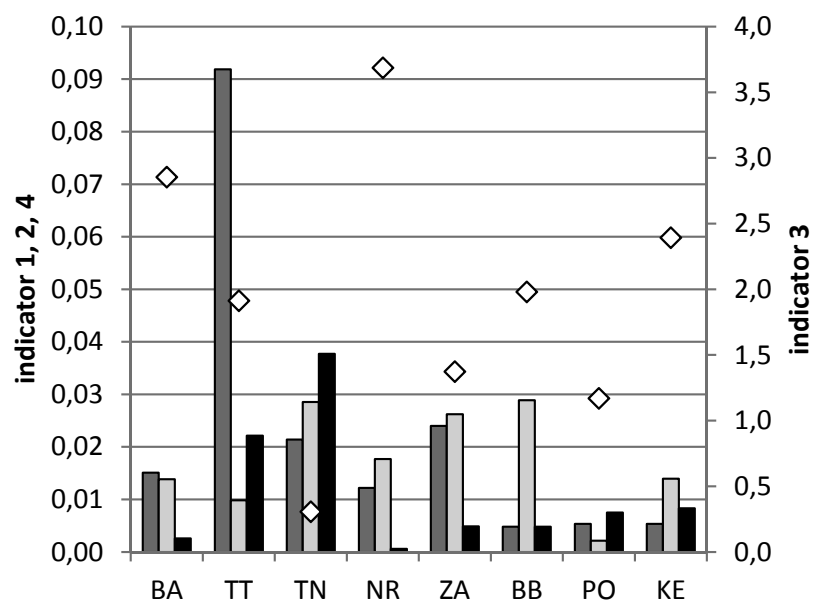

$\square 1$ - new materials, products and equipment

$\square 2$ - new processes, technological procedures

4 - patents and utility models

$\diamond 3$ - publications and citations

Figure 1. Selected indicators of innovation performance in the Slovak regions per one researcher in 2010 Source: own creating

Next, the innovation performance indicators in the Slovak regions were converted to standardized variables in line with the methodology described in the introduction of the paper. The results are shown in Table 2.

Table 2

Standardized variables of selected indicators in 2010

\begin{tabular}{|c|c|c|c|c|c|c|}
\hline & $\begin{array}{c}1-\text { new materials, } \\
\text { products and } \\
\text { equipment }\end{array}$ & $\begin{array}{c}2 \text { - new processes, } \\
\text { technological } \\
\text { procedures }\end{array}$ & $\begin{array}{c}3 \text { - publications } \\
\text { and citations }\end{array}$ & $\begin{array}{c}4 \text { - patents and } \\
\text { utility models }\end{array}$ & $\begin{array}{c}\text { integral indi- } \\
\text { cator } \mathrm{d}_{\mathrm{i}}\end{array}$ & $\begin{array}{c}\text { rank of the } \\
\text { region }\end{array}$ \\
\hline BA & $-0,2735461$ & $-0,4216298$ & 0,9140466 & $-0,7197312$ & $-0,5008605$ & 6 \\
\hline TT & 2,5589366 & $-0,8659955$ & $-0,0473843$ & 0,9396943 & 2,5852511 & 1 \\
\hline TN & $-0,0406574$ & 1,2120279 & $-1,6877000$ & 2,2601028 & 1,7437732 & 2 \\
\hline NR & $-0,3804588$ & 0,0051696 & 1,7631895 & $-0,8872748$ & 0,5006256 & 3 \\
\hline ZA & 0,0546109 & 0,9528907 & $-0,5982689$ & $-0,5245060$ & $-0,1152732$ & 5 \\
\hline BB & $-0,6527558$ & 1,2496541 & 0,0211413 & $-0,5307181$ & 0,0873215 & 4 \\
\hline PO & $-0,6328420$ & $-1,7220480$ & $-0,8070564$ & $-0,3033032$ & $-3,4652495$ & 8 \\
\hline KE & $-0,6332873$ & $-0,4100689$ & 0,4420320 & $-0,2342638$ & $-0,8355880$ & 7 \\
\hline
\end{tabular}

Source: own calculating. 
Following the calculations, it can be inferred that the highest innovation performance was in Trnava region in 2010. The first place is taken by Trnava region mainly for having the highest values per researcher in indicator 1. Trnava region had also the best results in indicator 4 .

Trnava region is followed by Trenčín region with the best results in indicator 4 . Trenčín region is followed by Nitra region with the best results in indicator 3. Above the average innovation performance were found in Banská Bystrica region. A significantly below the average of innovation performance in 2010 was found in Prešov region.

\section{THE ASSESSMENT OF INNOVATION PERFORMANCE OF THE SLOVAK REGIONS IN 2014}

The final year of our research is 2014 . The data of innovation performance per one researcher working in the given region for 2014 are shown in Table 3.

Table 3

Selected indicators of innovation performance of the Slovak regions per one researcher in 2014

\begin{tabular}{|c|c|c|c|c|}
\hline & $\begin{array}{c}1-\text { new materials, prod- } \\
\text { ucts and equipment }\end{array}$ & $\begin{array}{c}2 \text { - new processes, } \\
\text { technological } \\
\text { procedures }\end{array}$ & $\begin{array}{c}3 \text { - publications and } \\
\text { citations }\end{array}$ & $\begin{array}{c}4 \text { - patents and utility } \\
\text { models }\end{array}$ \\
\hline BA & 0,024455 & 0,024201 & 6,070437 & 0,002802 \\
\hline TT & 0,008278 & 0,014901 & 3,731788 & 0,003311 \\
\hline TN & 0,136872 & 0,025140 & 2,620112 & 0,078212 \\
\hline NR & 0,028680 & 0,017316 & 4,301948 & 0,074134 \\
\hline ZA & 0,029037 & 0,023757 & 2,001760 & 0,010559 \\
\hline BB & 0,011442 & 0,082380 & 2,530130 & 0,044241 \\
\hline PO & 0,005875 & 0,003525 & 3,502938 & 0,028202 \\
\hline KE & 0,013899 & 0,027797 & 5,670605 & 0,011814 \\
\hline
\end{tabular}

Source: own calculations on the basis of Ministry of Education, Science, Research and Sport of the Slovak Republic.

The largest share of new materials, products and equipment (indicator 1) per one researcher is found in Trenčín region, far followed by Žilina, Nitra and Bratislava regions. Regarding indicator 2 (new processes, technological procedures), the best results are seen in Banská Bystrica region, the worst results in Prešov region. Concerning publications and citations (indicator 3), Bratislava region has the largest productivity, followed by Košice region. Most patents and utility models per researcher are found in Trenčín and Nitra regions, while Bratislava and Trnava regions are lagging behind. A comparison of the productivity of researchers based on selected indicators of innovation performance in the Slovak regions is illustrated in Figure 2. 


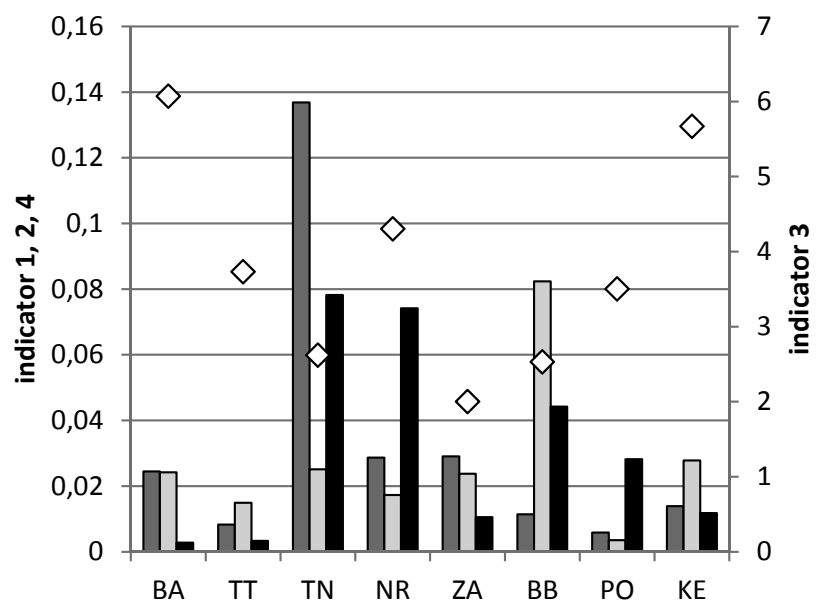

1 - new materials, products and equipment

$\square 2$ - new processes, technological procedures

4 - patents and utility models

$\diamond 3$ - publications and citations

Figure 2. Selected indicators of innovation performance in the Slovak regions per one researcher in 2014 Source: own creating.

Next, the innovation performance indicators in the Slovak regions were converted to standardized variables in line with the methodology described in the introduction of the paper. The results are shown in Table 4.

Table 4

Standardized variables of selected indicators in 2014

\begin{tabular}{|c|c|c|c|c|c|c|}
\hline & $\begin{array}{c}1-\text { new materi- } \\
\text { als, products and } \\
\text { equipment }\end{array}$ & $\begin{array}{c}2 \text { - new processes, } \\
\text { technological } \\
\text { procedures }\end{array}$ & $\begin{array}{c}3 \text { - publications } \\
\text { and citations }\end{array}$ & $\begin{array}{c}4 \text { - patents and } \\
\text { utility models }\end{array}$ & $\begin{array}{c}\text { integral indi- } \\
\text { cator } \mathrm{d}_{\mathrm{i}}\end{array}$ & $\begin{array}{c}\text { rank of the } \\
\text { region }\end{array}$ \\
\hline BA & $-0,1945040$ & $-0,1442388$ & 1,6424467 & $-1,0033913$ & 0,3003126 & 4 \\
\hline TT & $-0,5947462$ & $-0,5665620$ & $-0,0521173$ & $-0,9856906$ & $-2,1991161$ & 7 \\
\hline TN & 2,5867715 & $-0,1016015$ & $-0,8576280$ & 1,6186818 & 3,2462238 & 1 \\
\hline NR & $-0,0899942$ & $-0,4568790$ & 0,3610155 & 1,4768831 & 1,2910255 & 3 \\
\hline ZA & $-0,0811651$ & $-0,1643825$ & $-1,3056803$ & $-0,7336898$ & $-2,2849177$ & 8 \\
\hline BB & $-0,5164782$ & 2,4977173 & $-0,9228282$ & 0,4374725 & 1,4958833 & 2 \\
\hline PO & $-0,6541913$ & $-1,0831271$ & $-0,2179402$ & $-0,1202144$ & $-2,0754730$ & 6 \\
\hline KE & $-0,4556925$ & 0,0190737 & 1,3527318 & $-0,6900514$ & 0,2260616 & 5 \\
\hline
\end{tabular}

Source: own calculating.

Following the calculations, it can be inferred that the highest innovation performance was in Trencin region in 2014. The first place is taken by Trenčín region mainly for having the highest values per researcher in indicator 1 . Therefore, Trenčín region is the only having a positive value of standardized variable in indicator 1 . Trenčín region had also the best results in indicator 4 .

Trenčín region is followed by Banská Bystrica region with the best results in indicator 2. Banská Bystrica region is followed by Nitra region having positive values of standardized variables in indicators 3 and 4 . 
Above the average innovation performance were found in Bratislava and Košice regions. A significantly below the average of innovation performance in 2014 was found in Žilina, Trnava and Prešov regions.

\section{COMPARISON OF INNOVATION PERFORMANCE OF THE SLOVAK REGIONS OVER 2010-2014}

Since it is a long-term process to create innovations whose results can only be seen in the years to come, the innovation performance of the Slovak regions over 2010-2014 was assessed. The findings are shown in Figure 3.

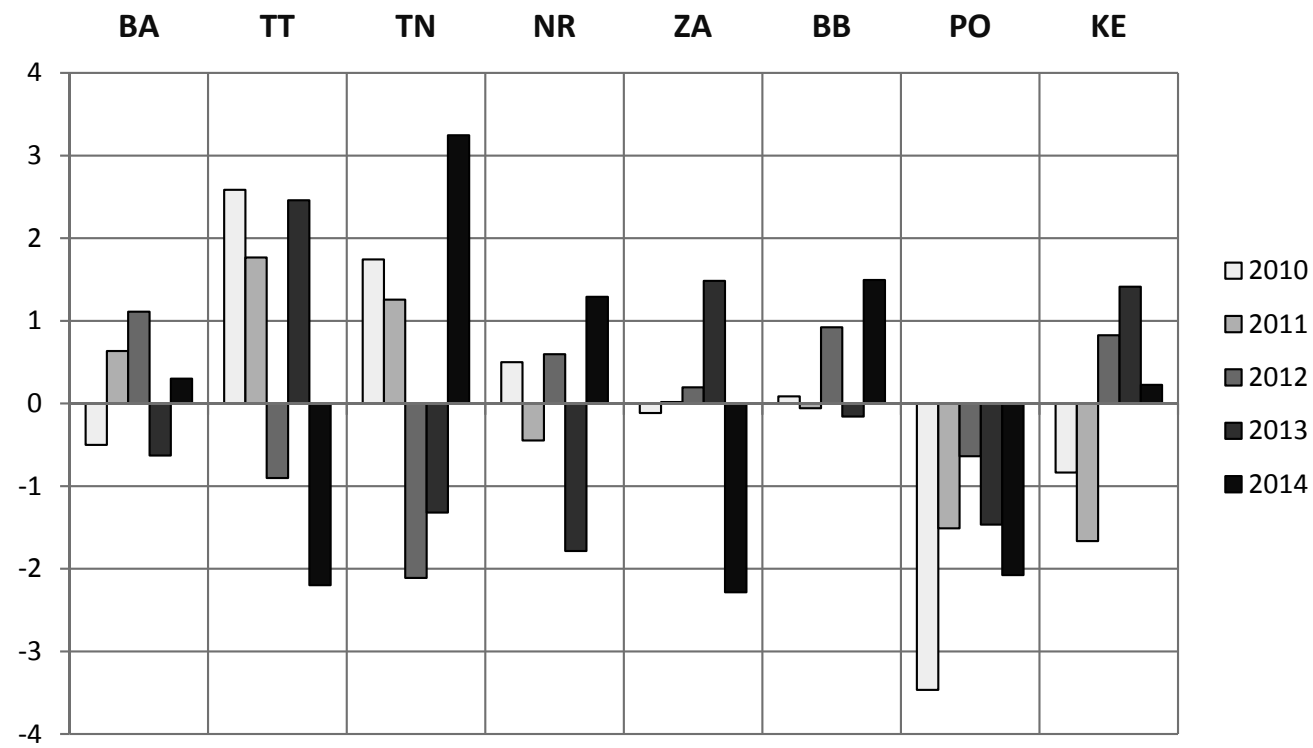

Figure 3. Comparison of innovation performance of the Slovak regions over 2010-2014

Source: own calculating, own creating.

Figure 3 indicates that the innovation performance of the Slovak regions was changing continually. While in 2010, 2011 and 2013 the highest value of the integral indicator was reached by Trnava region, in 2012 and 2014 its innovation performance was below the average level. In 2012, there were the slightest differences among regions, and the highest innovation performance was reached in Bratislava region. As already mentioned, the highest innovative performance was found in Trenčín region in 2014. The figure shows that the lowest innovation performance was reached by Prešov region, which had not overcome the national average in any of the years under consideration.

As for the entire reference period, totally best values were recorded in the Trnava region (3.710885), followed by Trenčín region (2.816204) and Banská Bystrica region (2.290026). Over-the average values were also recorded in Bratislava and Nitra regions. The markedly worst results (-9.156554) were recorded in Prešov region, and below-the-average results were also recorded in Žilina region (especially in 2014) and Košice region whose innovation performance has been improving recently. 
We realize that the findings on the innovation performance assessment utilizing a standard variable are affected by the selected variables and time series, as well as the markedly different values recorded in Bratislava region and the NUTS 3 assessment. NUTS3 level was chosen as the Statistical Office database provides detailed information on self-governing regions, i.e. NUTS 3.

\section{CONCLUSIONS}

Innovations play a significant role in the socio-economic development of national economies and regions. Innovations are a result of creative processes, new ideas, brain waves, and new knowledge.

The innovation performance of regions can be assessed in different ways using a number of indicators. In the paper, the following indicators were utilized to assess the performance of Slovak regions: number of new materials, products and equipment; number of processes, technological procedures, systems and services; number of publications and citations; number of patents and utility models. These indicator variables were calculated per number of researchers, and converted into standardized variables.

The innovation performance assessment of the Slovak regions made by utilizing a standardized variable and selected innovation performance-related indicators shows that there are significant differences among the regions of the SR and results are volatile in the reference periods.

Following the calculations, the highest innovation performance was achieved by Trnava region in 2010, which compared to other regions, excelled especially in the number of new processes and technological procedures. Trnava region was followed by Trenčín and Nitra regions.

In 2014, Trenčín region was found to achieve the best results, especially in the number of new materials, products and equipment. Trenčín region was followed by Banská Bystrica and Nitra regions.

When assessing the entire period under consideration, the best results were attributed to the regions of Western Slovakia (Trnava and Trenčín regions) and Banská Bystrica region. Above average values were also found in Bratislava and Nitra regions. The worst results were found in Prešov region, the region in which above average results were never reached over 2010-2014.

The findings related to the innovation performance in these regions are a reflection of the impact of the amount of expenditure on research and development, and primarily insufficient research and development funding. Innovations can be one of the means to mitigate regional disparities. It is therefore essential to ensure sufficient and efficient funding of research and development.

\section{ACKNOWLEDGMENTS}

The paper was written under the VEGA project No. 1/0233/16 "Dimensions and factors of social and economic development of regions in Visegrad Four countries".

\section{REFERENCES}

Act No. 172/2005 Coll. on the organization of state support for research and development

Drucker, P. F. (1993), Postcapitalist Society, New York: HerperCollins Publishers.

Edquist, C. (1997), Systems of Innovation: Technologies, Institutions and Organisations, London: Pinter Publishers.

Freeman, C. (1987), Technology policy and economic performance: lessons from Japan. London: Pinter. 
Harmaakorpi, V. (2004), Building a competitive regional innovation environment - The regional development platform method as a tool for regional innovation policy, Helsinki, University of Technology, pp. 13 - 132.

Havierniková, K., Strunz, H. (2014), The comparison of selected methods used for identification of cluster potential in the regions of the Slovak Republic, SGEM conference on political sciences law, finance economics \& tourism: Conference proceedings volume IV. Economic \& tourism, Sofia: STEF92 Technology, pp. 693-699.

Kačírková, M. (2009), Formovanie spolupracujúceho regionálneho inovačného prostredia, Working Papers, no. 18, Bratislava: Ekonomický ústav SAV.

Lundvall, B-Å. (ed.) (1992), National Systems of Innovation: Towards a Theory of Innovation and Interactive learning, London: Pinter Publishers.

Ministry of Education, Science, Research and Sport of the Slovak Republic - Central Information Portal 2016 Statistical Indicators // http://econ.worldbank.org (referred on 24/03/2016).

OECD 2005 Oslo Manual - Guidelines for collecting and interpreting innovation data // http://www.oecd-ilibrary.org/ science-and-technology/oslo-manual_9789264013100-en (referred on 04/04/2016).

OECD 2005 Oslo Manual: Proposed Guidelines for Collecting and Interpreting Technological Innovation Data // https:/www.oecd.org/innovation/inno/oslomanualproposedguidelinesforcollectingandinterpretingtechnologicalinnovationdata2ndedition.htm (referred on 30/03/2016).

Okręglicka, M. (2016), Internal innovativeness and management of current finances of enterprises in Poland, Business Challenges in the Changing Economic Landscape, Vol. 1, pp. 225-237.

Porter, M. E. (1990), The Competitive Advantage of Nations. New York: The Free Press.

Rajnoha, R., Lorincová, S. (2015), Strategic Management of Business Performance Based on Innovations and Information Support in Specific Conditions of Slovakia, Journal of Competitiveness, Vol. 7, no. 1, pp. 3-21.Rothwell, R. and Gardiner, P. (1988), Re-Innovation and Robust Designs: Producer and User Benefits, Journal of Marketing Management, Vol. 3, pp. 64-72.

Ručínska, S. (2008), Konkurencieschopnost' regiónov s dôrazom na inovácie. Transfer inovácií. 12/2008, ISSN 1337 7094, pp.181-185.

// http://www.sjf.tuke.sk/transferinovacii/pages/archiv/transfer/12-2008/pdf/181-185.pdf.

Schumpeter, J.A. (1934), The Theory of Economic Development. An Inquiry into Profits, Capital, Credit, Interest, and the Business Cycle, Cambridge: Harvard University Press.

Sedláček, M. (2014), Analyse of innovation performance of Slovak Republic regions and main factors of regional development based on innovation, SGEM conference on political sciences law, finance economics \& tourism : Conference proceedings volume IV Economics \& tourism, Sofia: STEF92 Technology, pp. 27-34.

Skokan, K. (2004), Konkurencieschopnost, inovace a klastry v regionálním rozvoji, Ostrava: Repronis.

Teece, D. J., Pisano, G,\& Shuen, A. (1997), Dynamic Capabilities and Strategic Management, Strategic Management Journal, Vol. 18, no. 7, pp. 509-533.

Tödtling, F., Trippl, M. (2005), One size fits all? Towards a differentiated regional innovation policy approach, Research Policy Vol. 34, no 8, pp. 1203-1219.

Urbančíková, N., Burger, P. (2010), Miera regionalizácie inovačných politík a jej vplyv na inovačnú výkonnost́ regiónov, E +M Ekonomie a management, Vol. 13, no. 1, pp. 23-36.

Urbancová H. (2013), Competitive Advantage Achievement through Innovation and Knowledge, Journal of Competitiveness, Vol. 5, no. 1, pp. 82-96.

www.oecd.org. http://www.oecd.org/publications/frascati-manual-2015-9789264239012-en.htm.

Zastempowski, M., Przybylska, N. (2016), Cooperation in Creating Innovation in Polish Small and Medium-Sized Enterprises in the Light of Empirical Studies, Journal of Competitiveness, Vol. 8, no. 2, pp. 42-58. 